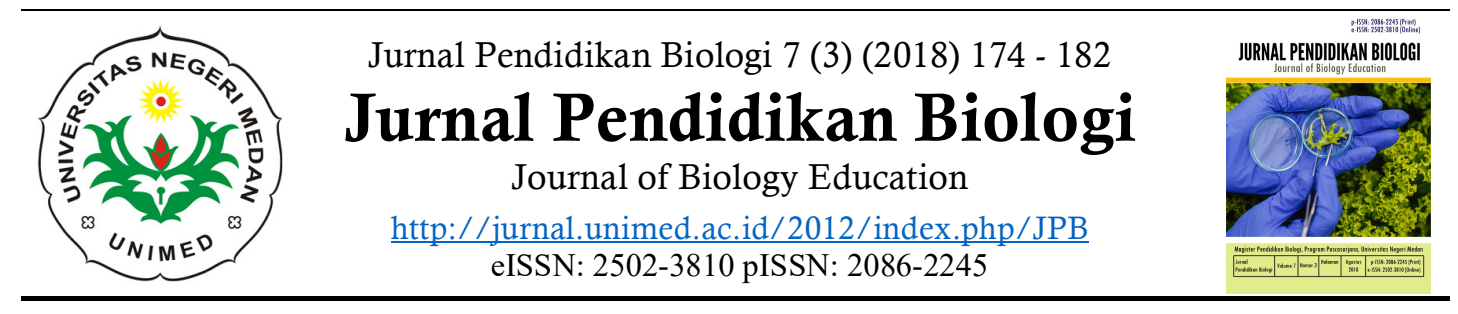

\title{
Profil Keterampilan Argumentasi Siswa Kelas X dan XI MIPA di SMA Batik 1 Surakarta pada Materi Keanekaragaman Hayati
}

\author{
Nurul Faiqoh", Nadhirotul Khasanah, Lia Puji Astuti ${ }^{* *}$, Riski Prayitno, \\ Baskoro Adi Prayitno \\ Program Studi Pendidikan Biologi, Fakultas Keguruan dan Ilmu Keguruan, Universitas \\ Sebelas Maret, J1. Ir. Sutami No.36A, Jebres, Kota Surakarta, Jawa Tengah 57126, \\ Indonesia \\ Korespondensi: *nurul.faiq@student.uns.ac.id; **lia puji@student.uns.ac.id
}

DOI: https://doi.org/10.24114/jpb.v7i3.10122

\begin{abstract}
The research aims to know the argumentation skill profile and the difference of students' argumentation skill between $10^{\text {th }}$ MS (Match and Science) and $11^{\text {th }}$ MS in Batik 1 Senior High School of Surakarta on Biodiversity material. The type of research is descriptive quantitative using survey method. Population research is all students or 400 students of class $10^{\text {th }}$ and $11^{\text {th }}$ MS in SMA Batik 1 Surakarta. Sampling technique using stratified proportional random sampling. The instrument to measure the skills of the user is using essay handbooks. Analysis of argumentability was using Toulmin's Argumentation Pattern (TAP). The data were analyzed using quantitative descriptive. The results showed the quality of the students' argumentation in one of the Private High School Surakarta in sufficient category. Percentage of achievement of each indicator is $68 \%$ claim, $60 \%$ warrant, $53 \%$ data, $45 \% \mathrm{~s}$ backing and $0 \%$ rebuttal. The result of t-test got sig. (2-tailed) about 0.002 . therefore we can conclude that argumentation skill of $10^{\text {th }}$ and $11^{\text {th }}$ MS in SMA Batik 1 Surakarta have significant differences of class $\mathrm{X}$ and XI argumentation skill shows a significant differences, although the argumentation skill quality of both cluster class is enough.
\end{abstract}

Keywords: Argumentation, Diversity, Toulmin's Argumentation Pattern (TAP)

\section{PENDAHULUAN}

Tantangan keterampilan abad 21 di Indonesia dihadapi dengan penerapan Kurikulum 2013 untuk meningkatkan proses ilmiah dan penalaran. Pembelajaran Kurikulum 2013 didasarkan pada model "pendekatan ilmiah" yang memungkinkan siswa menemukan bukti dan alasan. Keterampilan berpikir kritis dikembangkan bersama dengan membangun keterampilan argumentasi (Sumarni, et al., 2017). Keterampilan argumentasi digunakan oleh seseorang untuk menganalisis informasi mengenai suatu topik, kemudian hasil analisis dikomunikasikan kepada orang lain, dengan demikian penggunaan argumentasi dalam pembelajaran sains adalah bagian dari pengembangan keterampilan berpikir tingkat tinggi (Sumarni, et al., 2017). Pembelajaran memberikan kesempatan kepada siswa agar terlibat dan belajar menggunakan 
keterampilan berpikir secara ilmiah. Konsep-konsep sains dibelajarkan melalui konstruksi wacana argumentatif yang merupakan esensi praktek inkuiri ilmiah (Farida \& Gusniarti, 2014).

Keterampilan argumentasi menjadi salah satu tujuan utama pembelajaran sains karena siswa yang belajar sains harus mengetahui penjelasan ilmiah mengenai fenomena alam dan menggunakan argumentasi untuk memecahkan masalah sehingga mampu memahami temuan lain yang siswa dapatkan. Siswa yang mengerti sains secara utuh harus memahami bahasa sains dan berpartisipasi secara aktif dalam kegiatan ilmiah seperti observasi dan argumentasi (Probosari, et al., 2016). Keterampilan argumentasi sangat penting untuk dilatihkan di dalam pembelajaran sains sehingga peserta didik memiliki nalar yang logis, pandangan yang jelas dan penjelasan yang rasional dari hal-hal yang dipelajari. Kegiatan pembelajaran yang berbasis argumentasi mendorong peserta didik untuk terlibat dalam memberikan bukti, data, dan teori yang valid untuk mendukung pendapat (klaim) terhadap suatu permasalahan (Ginanjar, et al., 2015).

Argumentasi adalah aktivitas kognitif dalam membangun pengetahuan sains (Viyanti, et al., 2016). Argumentasi digunakan untuk memperkuat suatu klaim melalui analisis berpikir kritis berdasarkan dukungan bukti-bukti dan alasan yang logis. Berdasarkan Toulmin's Argumentation Pattern (TAP) komponen argumentasi terdiri atas data (data), klaim (claim), pembenaran (warrant), dukungan (backing), dan sanggahan (rebuttal). Data merupakan fenomena yang digunakan sebagai bukti untuk mendukung klaim. Klaim adalah hasil dari nilai-nilai yang ditetapkan, pendapat mengenai nilai situasi yang ada atau penegasan dari sudut pandang. Pembenaran adalah aturan dan prinsip-prinsip yang menjelaskan hubungan antara data dan klaim. Dukungan adalah dasar asumsi yang melandasi pembenaran tertentu. Sanggahan adalah kasus-kasus tertentu saat klaim tidak dapat dibuktikan (verified) atau adanya argumenargumen yang berbeda (Ginanjar, et al., 2015).

Keterampilan argumentasi siswa yang rendah berdampak pada hasil belajar. Siswa dengan keterampilan argumentasi rendah tidak akan mampu bersaing di kehidupan yang semakin maju dan kehilangan kesempatan kerja yang baik. Permasalahan yang dihadapi siswa tidak mampu diselesaikan secara efektif sehingga siswa kesulitan menghadapi tantangan di kehidupan yang semakin kompleks (Muslim \& Suhandi, 2012). Penelitian ini bertujuan untuk mengetahui profil keterampilan berargumentasi dan perbedaan keterampilan berargumentasi peserta didik kelas $X$ dan XI MIPA di SMA Batik 1 Surakarta pada materi Keanekaragaman Hayati.

\section{METODE PENELITIAN}

\section{Metode}

Penelitian yang dilakukan adalah deskriptif kuantitatif dengan metode survei. Populasi penelitian adalah seluruh siswa kelas X dan XI MIPA di SMA Batik 1 Surakarta yang berjumlah 400 siswa. Teknik sampling menggunakan stratified proportional random sampling. Pengambilan sampel diperoleh dari populasi sejumlah 400 siswa kelas dari X dan XI MIPA (masing-masing 5 kelas) kemudian diambil 7,5\% yaitu sebesar 30 siswa. Setiap kelas diambil 3 siswa secara acak sehingga diperoleh sampel sejumlah 30 siswa, dengan 15 siswa kelas X MIPA dan 15 siswa kelas XI MIPA. Pengambilan sampel dilakukan dengan skema seperti disajikan pada Gambar 1. 


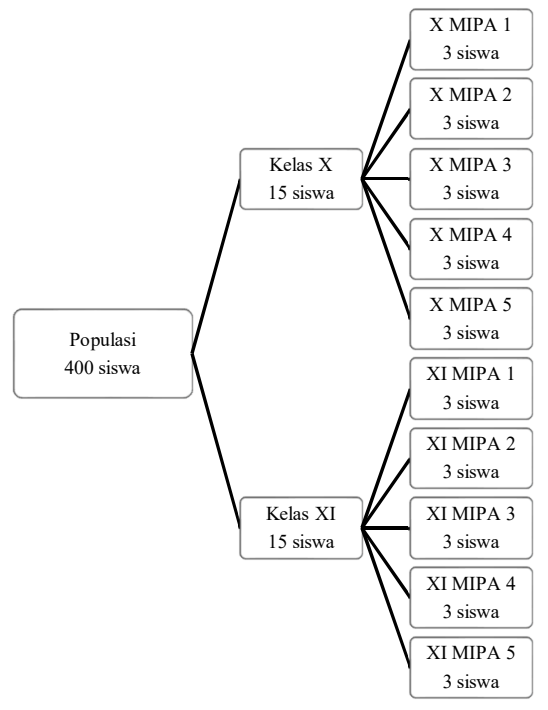

Gambar 1. Pengambilan Sampel

Instrumen yang digunakan untuk mengukur keterampilan argumentasi menggunakan tes essai. Kualitas keterampilan argumentasi dinilai menggunakan TAP (Toulmin's Argumentation Pattern). Prosedur pengambilan data keterampilan argumentasi dilakukan dengan memberikan tes essai yang berjumlah 5 butir soal dengan ketentuan lama waktu mengerjakan 15 menit.

\section{Analisis Data}

Analisis data menggunakan analisis deskriptif kuantitatif dan $t$ test independent, perhitungan menggunakan bantuan Microsoft Excel versi 2013 dan SPSS versi 22 dengan taraf signifikansi 0,05 . Analisis data dilakukan melalui tiga komponen, meliputi: reduksi data, penyajian data, dan penarikan kesimpulan. Analisis data menggunakan perhitungan rata-rata, standar deviasi untuk siswa kelas $\mathrm{X}$ dan XI MIPA, dan perhitungan standar deviasi gabungan keduanya untuk mengetahui beda nyata keterampilan argumentasi antara siswa kelas $\mathrm{X}$ dan XI MIPA. Keterampilan argumentasi siswa diukur menggunakan tes essai yang dikembangkan berdasarkan indikator argumentasi siswa menurut Toulmins Argumentation Pattern (TAP) dan pengukuran argumentasi menurut (Budiyono, 2016).

Tabel 1. Pedoman Penilaian Tes Keterampilan Berargumentasi

\begin{tabular}{|c|c|c|c|c|c|}
\hline \multirow{2}{*}{ No } & \multicolumn{2}{|c|}{ Keterampilan Argumentasi } & \multicolumn{3}{|c|}{ Kriteria dan Skor } \\
\hline & Unsur & Aspek & 1 & 2 & 3 \\
\hline 1 & Klaim & $\begin{array}{l}\text { Akurasi } \\
\text { klaim }\end{array}$ & $\begin{array}{l}\text { Klaim sepenuhnya } \\
\text { tidak akurat }\end{array}$ & $\begin{array}{l}\text { Klaim sebagian } \\
\text { akurat }\end{array}$ & $\begin{array}{l}\text { Klaim sepenuhnya } \\
\text { akurat }\end{array}$ \\
\hline \multirow[t]{2}{*}{2} & Data & $\begin{array}{l}\text { Kecukupan } \\
\text { data }\end{array}$ & $\begin{array}{l}\text { Menyertakan data } \\
\text { tetapi tidak relevan } \\
\text { untukmendukung } \\
\text { klaim }\end{array}$ & $\begin{array}{l}\text { Menyertakan } \\
\text { data, tetapi tidak } \\
\text { cukup untuk } \\
\text { mendukung klaim }\end{array}$ & $\begin{array}{l}\text { Menyertakan data } \\
\text { yang cukup untuk } \\
\text { mendukung klaim }\end{array}$ \\
\hline & & Kualitas data & $\begin{array}{l}\text { Data ada tetapi } \\
\text { tidak dianalisis } \\
\text { untukmendukung } \\
\text { klaim }\end{array}$ & $\begin{array}{l}\text { Data sebagian } \\
\text { dianalisis untuk } \\
\text { mendukung klaim }\end{array}$ & $\begin{array}{l}\text { Data sepenuhnya } \\
\text { dianalisis untuk } \\
\text { mendukung klaim }\end{array}$ \\
\hline 3 & Pembenaran & $\begin{array}{l}\text { Kualitas } \\
\text { pembenaran }\end{array}$ & $\begin{array}{l}\text { Pembenaran } \\
\text { untukmenjelaskan } \\
\text { hubungan antara } \\
\text { data dan klaim } \\
\text { tidak mendukung } \\
\text { klaim }\end{array}$ & $\begin{array}{l}\text { Pembenaran } \\
\text { untuk } \\
\text { menjelaskan } \\
\text { hubungan antara } \\
\text { data dan klaim } \\
\text { sebagian } \\
\text { mendukung klaim }\end{array}$ & $\begin{array}{l}\text { Pembenaran untuk } \\
\text { menjelaskanhubungan } \\
\text { antara data dan klaim } \\
\text { sepenuhnya } \\
\text { mendukung klaim }\end{array}$ \\
\hline 4 & Dukungan & $\begin{array}{l}\text { Kualitas } \\
\text { dukungan }\end{array}$ & $\begin{array}{l}\text { Dukungan untuk } \\
\text { melandasi } \\
\text { pembenaran tidak } \\
\text { mendukung klaim }\end{array}$ & $\begin{array}{l}\text { Dukunganuntuk } \\
\text { melandasi } \\
\text { pembenaran } \\
\text { sebagian } \\
\text { mendukung klaim }\end{array}$ & $\begin{array}{l}\text { Dukunganuntuk } \\
\text { melandasi pembenaran } \\
\text { sepenuhnya } \\
\text { mendukung klaim }\end{array}$ \\
\hline
\end{tabular}

Sumber: (Budiyono, 2016) 
Persentase Nilai akhir Keterampilan argumentasi siswa dihitung dengan membandingkan jumlah skor siswa dengan skor total. Kriteria interpretasi skornya berdasarkan interval:

$0 \%-19,99 \%=$ Sangatburuk

$20 \%-39,99 \%=$ Kurangbaik

$40 \%-59,99 \%=$ Cukup

$60 \%-79,99 \%=$ Baik

$80 \%-100 \%=$ Sangat Baik

\section{HASIL DAN PEMBAHASAN}

\section{Hasil}

Keterampilan argumentasi adalah kemampuan siswa untuk menarik kesimpulan sebagai sebuah keputusan dari informasi yang tersedia dan dan berdasarkan fakta (wahdan, et al., 2017). Toulmin menyebutkan bahwa argumentasi terdiri dari 5 komponen, yaitu data (data), klaim (claim), pembenaran (warrant), dukungan (backing), dan sanggahan (rebuttal) (cetin, 2014). Data adalah fenomena yang digunakan sebagai bukti untuk mendukung klaim. Klaim adalah hasil dari nilai-nilai yang ditetapkan, pendapat mengenai nilai situasi yang ada, atau penegasan dari sudut pandang. Pembenaran adalah aturan dan prinsip-prinsip yang menjelaskan hubungan antara data dan klaim. Dukungan adalah dasar asumsi yang melandasi pembenaran tertentu. Sanggahan adalah kasus-kasus tertentu ketika klaim tidak dapat dibuktikan (verified) atau adanya argumen-argumen yang berbeda (Budiyono, 2016).

Data hasil pengamatan pada gambar grafik 1 menunjukkan keterampilan argumentasi siswa kelas $\mathrm{x}$ dan XI MIPA sma Batik 1 Surakarta memiliki pemenuhan unsur argumentasi sebagai berikut: 68\% siswa menggunakan klaim ketika berargumentasi, $60 \%$ siswa menyertakan warrant (pembenaran atau alasan), 52\% siswa menggunakan data (bukti) dengan benar, 44\% siswa menggunkana backing (dukungan atau sumber) dan $0 \%$ rebuttal (sanggahan) (Gambar 2).

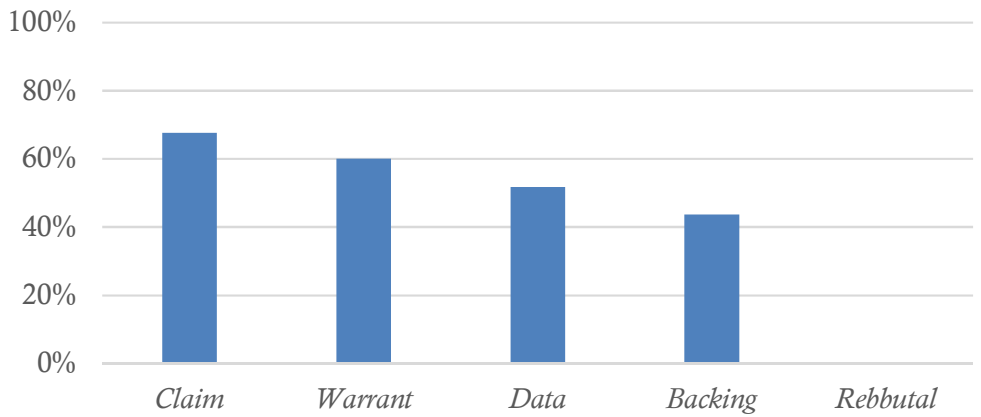

Gambar 2. Persentase unsur argumentasi siswa SMA Batik 1 Surakarta kelas X dan XI.

Data komunal di kelas X dan XI MIPA SMA Batik 1 Surakarta yang diperoleh kemudian dibandingkan, untuk mengetahui perbedaan keduanya. Hasilnya dapat dilihat pada grafik Gambar 3, yang menunjukkan perbedaan persentase masing-masing unsur kemampuan argumentasi antara keals X MIPA dan kelas XI MIPA. Kelas XI MIPA memiliki persentase yang lebih tinggi dibanding kelas $\mathrm{X}$ MIPA. Perbedaan keterampilan argumentasi siswa kelas $\mathrm{X}$ MIPA dan XI MIPA memiliki beda signifikan, yaitu ditunjukkan dengan $t$ test pada tabel 1 bagian sig (2-tailed) 0,002 yang lebih rendah dibanding 0,05 (Tabel 1). 


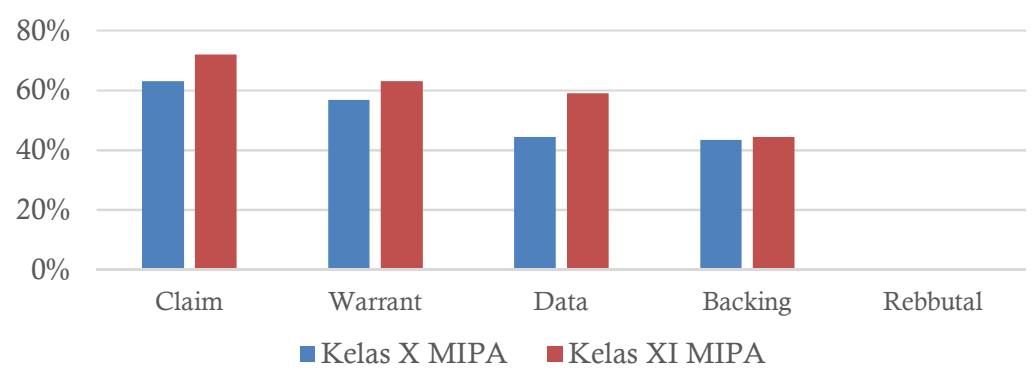

Gambar 3. Perbedaan persentase unsur argumentasi siswa SMA Batik 1 Surakarta pada materi kaenekaragaman hayati.

Tabel 1. Uji t test perbedaan keterampilan argumentasi siswa kelas X MIPA dan XI MIPA SMA Batik 1 Surakarta.

\begin{tabular}{|c|c|c|c|c|c|c|}
\hline & \multicolumn{6}{|c|}{ Test Value $=0$} \\
\hline & \multirow[t]{2}{*}{$\mathrm{t}$} & \multirow[t]{2}{*}{ df } & \multirow{2}{*}{$\begin{array}{l}\text { Sig. (2- } \\
\text { tailed) }\end{array}$} & \multirow{2}{*}{$\begin{array}{c}\text { Mean } \\
\text { difference }\end{array}$} & \multicolumn{2}{|c|}{$\begin{array}{l}95 \% \text { Confidence Interval of the } \\
\text { Difference }\end{array}$} \\
\hline & & & & & Lower & Upper \\
\hline Kelas X MIPA & 10.688 & 3 & .002 & .51850 & .3641 & .6729 \\
\hline Kelas XI MIPA & 10.193 & 3 & .002 & .59550 & .4096 & .7814 \\
\hline
\end{tabular}

Sumber: data hasil penelitian; Analisis: SPSS Versi 22

Keterangan:

Nilai Sig. (2-tailed) 0,002 kurang dari $\alpha=0,05$, sehingga keterampilan argumentasi siswa kelas X MIPA dan XI MIPA SMA Batik 1 Surakarta memiliki perbedaan yang signifikan.

Unsur-Unsur Keterampilan Argumentasi

Unsur-unsur keterampilan argumentasi dianalisis dalam bentuk persetase kemudian dikonversi menjadi kategori kualitas. Keterampilan argumentasi siswa SMA Batik 1 Surakarta berada pada kisaran kategori kurang baik sampai baik. Kualitas unsur argumentasi setiap kelas pada setiap jenjang berbeda-beda, yang secara tidak langsung menentukan kualitas kelas dalam berargumentasi. Kualitas klaim siswa kelas $\mathrm{X}$ MIPA memiliki kategori baik, sama dengan kelas XI MIPA. Hanya saja, keduanya memiliki selisih persentase berbeda, tetapi dalam kategori kualitas yang sama. Berikut adalah tabel kualitas masingmasing unsur keterampilan argumentasi siswa.

Tabel 2. Kualitas Klaim Siswa Kelas X MIPA dan XI MIPA

\begin{tabular}{ccc}
\hline Kelas & \% Kualitas Klaim & Kategori \\
X MIPA 1 & $60 \%$ & Baik \\
X MIPA 2 & $55,5 \%$ & Cukup \\
X MIPA 3 & $77,7 \%$ & Baik \\
X MIPA 4 & $66,7 \%$ & Baik \\
X MIPA 5 & $55,5 \%$ & Cukup \\
XI MIPA 1 & $95,5 \%$ & Sangat baik \\
XI MIPA 2 & $66,7 \%$ & Baik \\
XI MIPA 3 & $71,1 \%$ & Baik \\
XI MIPA 4 & $68,9 \%$ & Baik \\
XI MIPA 5 & $57,8 \%$ & Cukup \\
\hline
\end{tabular}


Rata-rata kualitas klaim siswa kelas $\mathrm{X}$ MIPA adalah $63 \%$ dengan kategori cukup, sedangkan rata-rata kualitas klaim siswa kelas XI MIPA 72\% dengan kategori baik (Tabel 2). Kualitas klaim ditinjaun dari keakuratan klaim. Klaim siswa pada kelima jawaban soal rata-rata 3 adalah benar dan 2 salah. Klaim berupa jawaban singkat dari pertanyaan seputar keanekaragaman hayati. Siswa banyak yang mengalami kesulitan pada soal nomor 4 dan 5 yaitu menentukan bagian laut yang banyak memiliki keanekaragaman dan menentukan garis wellace-weber pada peta. Kedua soal menjadi sulit dikerjakan siswa karena jawaban sangat berdasar pada pengetahuan siswa sebelumnya,bukan hanya sebatas penalaran logika. Jika, konsep yang dimiliki siswa tidak menyeluruh, maka jawaban yang diberikan siswa juga cenderung salah.

Tabel 3. Kualitas Data Siswa Kelas X MIPA dan XI MIPA

\begin{tabular}{ccc}
\hline Kelas & \% Kualitas Data & Kategori \\
\hline X MIPA 1 & $20 \%$ & Kurang baik \\
X MIPA 2 & $42,2 \%$ & Cukup \\
X MIPA 3 & $82,2 \%$ & Sangat baik \\
X MIPA 4 & $55,6 \%$ & Cukup \\
X MIPA 5 & $22,2 \%$ & Kurang baik \\
XI MIPA 1 & $82,2 \%$ & Sangat baik \\
XI MIPA 2 & $60 \%$ & Baik \\
XI MIPA 3 & $57,8 \%$ & Cukup \\
XI MIPA 4 & $42,2 \%$ & Cukup \\
XI MIPA 5 & $53,3 \%$ & Cukup \\
\hline
\end{tabular}

Tabel 4. Kualitas Warrant Siswa Kelas X MIPA

\begin{tabular}{ccc}
\hline Kelas & \% Kualitas Warrant & Kategori \\
\hline X MIPA 1 & $57,8 \%$ & Cukup \\
X MIPA 2 & $46,7 \%$ & Cukup \\
X MIPA 3 & $60 \%$ & Baik \\
X MIPA 4 & $46,7 \%$ & Cukup \\
X MIPA 5 & $73,3 \%$ & Baik \\
XI MIPA 1 & $86,7 \%$ & Sangat baik \\
XI MIPA 2 & $68,8 \%$ & Baik \\
XI MIPA 3 & $60 \%$ & Baik \\
XI MIPA 4 & $48,9 \%$ & Cukup \\
XI MIPA 5 & $51,1 \%$ & cukup \\
\hline
\end{tabular}

Rata-rata kualitas warrant siswa kelas X MIPA adalah 56,90\% dengan kategori cukup, sedangkan rata-rata kualitas warrant siswa kelas XI MIPA 63,10\% dengan kategori baik (Tabel 3). Rata-rata kualitas data siswa kelas X MIPA adalah 44\% dengan kategori cukup, sedangkan rata-rata kualitas data siswa kelas XI MIPA 59,10\% dengan kategori cukup (Tabel 4). Kualitas data yang digunakan siswa kelas X MIPA dan XI MIPA untuk berargumentasi termasuk dalam kategori cukup. Kualitas data ditinjau dari relevansi data dan penggunaan data dalam analisis untuk mendukung klaim. Kualitas warrant (pembenaran) atau alasan siswa kelas $\mathrm{X}$ MIPA berada dalam kategori cukup, sedangkan siswa kelas XI MIPA kategori kualitasnya rata-rata baik. Kualitas warrant ditinjau dari kemampuan warrant menjelaskan hubungan antara data dan klaim (Budiyono, 2016). Rata-rata siswa memberikan data atau bukti yang diberikan berdasarkan pengalaman siswa sehari-hari, tetapi bukti yang berikan tidak mampu mendukung klaim dengan baik, sehingga 
anatar klaim dengan data seolah tidak memeliki keterkaitan. Soal nomor 4 dan 5 (merujuk pada paragraf yang menjelaskan tentang klaim) adalah soal yang paling banyak tidak diberi bukti, dari 30 siswa subyek penelitian, hanya 13 siswa yang memberikan bukti atau data. Siswa cenderung kebingungan untuk menjawab soal yang disertai pembuktian, karena selama ini siswa tidak dibiasakan untuk memberikan bukti pada setiap jawab soal essay.

Tabel 5. Kualitas Backing Siswa Kelas X MIPA dan XI MIPA

\begin{tabular}{ccc}
\hline Kelas & \% Kualitas Backing & Kategori \\
\hline X MIPA 1 & $35,5 \%$ & Kurang baik \\
X MIPA 2 & $28,9 \%$ & Kurang baik \\
X MIPA 3 & $55,5 \%$ & Cukup \\
X MIPA 4 & $28,9 \%$ & Kurang baik \\
X MIPA 5 & $68,9 \%$ & Baik \\
XI MIPA 1 & $57,7 \%$ & Cukup \\
XI MIPA 2 & $48,8 \%$ & Cukup \\
XI MIPA 3 & $46,7 \%$ & Cukup \\
XI MIPA 4 & $37,8 \%$ & Kurang baik \\
XI MIPA 5 & $28,8 \%$ & Kurang baik \\
\hline
\end{tabular}

Rata-rata kualitas backing siswa kelas X MIPA adalah 44\% dengan kategori cukup, sedangkan rata-rata kualitas backing siswa kelas XI MIPA 59,10\% dengan kategori cukup (Tabel 5). Kualitas backing (dukungan) atau dalam penelitian ini disebut dengan sumber siswa di kelas $\mathrm{X}$ MIPA dan XI MIPA memiliki kategori cukup. Backing merupakan unsur yang sangat jarang diterapkan dalam pembelajaran di tingkat SMA. Empat dari lima soal yang diberikan rata-rata siswa tidak mampu memberikan sumber yang dapat mendukung alasan atau pembenaran. Kualitas backing ditinjau dari keamampuan dukungan dalam melandasi warrant (pembenaran) yang mendukung klaim (Budiyono, 2016). Penggunaan backing berupa sumber banyak digunakan pada senjang perguruan tinggi. Oleh karena itu, siswa SMA ketika diminta memberikan sumber pada jawaban, cenderung memberikan jawaban yang asal, sehingga berdampak pada kualitas backing dan keterampilan argumentasinya (Wahdan, et al., 2017).

\section{Pembahasan}

Hasil analisis data diketahui bahwa siswa kelas X MIPA yang menggunakan klaim dalam berargumentasi sebanyak $63,11 \%$, sedangkan siswa kelas XI MIPA sebanyak 72,00\%. Hasil menunjukkan bahwa siswa kelas XI memiliki kemampuan menjawab lebih baik dibanding kelas $\mathrm{X}$. Jawaban benar yang diberikan siswa dipengaruhi oleh tingkat pemahaman siswa terhadap materi. Jika pemahaman terhadap materi kurang, maka jawaban yang diberikan cenderung salah, sehingga kualitas klaimnya kurang baik (Handayani, et al., 2015). Sebanyak $56,88 \%$ siswa $X$ MIPA memberikan warrant (pembenaran atau alasan) pada jawaban yang diberikan, sedangkan kelas XI MIPA lebih banyak lagi, yaitu sebesar 63,10\%. Jawaban yang diberikan oleh siswa belum memiliki alasan yang tepat dan logis, padahal materi keanekaragaman merupakan materi semester 1 kelas X MIPA (Nurichah, et al., 2012). $44,40 \%$ siswa kelas $X$ MIPA menggunakan data atau bukti di setiap jawaban yang diberikan, sedangkan siswa kelas XI MIPA yang menggunakna data dalam jawaban adalah $59,11 \%$ siswa. 
Kemampuan berfikir konkret dan membuat sebuah hubungan pada sebuah masalah (soal) berkembang lebih matang di jenjang yang lebih tinggi (Amin, 2010). Perkembangan yang terjadi berhubungan dengan faktor usia dan proses perkembanagan berfikir peserta didik (Ibda, 2015). 43,50\% siswa kelas $X$ MIPA memberikan backing atau dukungan jawaban dengan mencantumkan sumber jawaban yang diberikan, sedangkan kelas XI MIPA sebanyak 44,40\%. Persentase unsur backing kelas X MIPA dan XI MIPA tidak memiliki selisih yang banyak, karena pemberian sumber dalam penyelesaiaan masalah atau soal di tingkat SMA belum terlalu ditekankan, berbeda dengan jenjang sarjana atau diploma (Wahdan, et al., 2017).

Perbedaan kualitas kedua jenjang kelas pada semua unsur argumentasi adalah signifikan. Tetapi keduanya berada dalam kategori cukup dengan rentan nilai yang berbeda (Miles, 1992). Keterampilan argumetasi dengan kategori cukup perlu ditingkatkan untuk mengoptimalkan keterampilan argumentasi. Toulmin berpendapat bahwa argumentasi yang baik dilakukan dengan langkah berikut: menyatakan suatu pendirian (standpoint) berupa pendapat atau pernyataan, dalam istilah Toulmin, pendapat diberi nama claim. Claim yang diajukan harus didukung oleh data hubungan keduanyadijembatani oleh pembenaran (warrant). Data-warrantclaim merupakan struktur dasar suatu argumentasi. Argumentasi dapat didefnisikan sebagai suatu upaya untuk membentuk atau memvalidasi klaim atas dasar alasan. Klaim dalam kerangka ini adalah sebuah dugaan, penjelasan, kesimpulan, prinsip digeneralisasikan, atau jawaban atas pertanyaan penelitian. Bukti komponen argumen mengacu pada data (yaitu, pengukuran atau pengamatan) yang telah dikumpulkan sebagai bagian dari investigasi dan kemudian dianalisa dan diinterpretasikan oleh para ilmuwan. Alasan yang merupakan komponen dari sebuah argumen mengacu pada pernyataan yang menjelaskan bagaimana bukti dapat mendukung klaim dan mengapa bukti harus dihitung untuk mendukung klaim (Wahdan, et al., 2017).

\section{KESIMPULAN}

Berdasarkan hasil penelitian dan pembahasan diperoleh bahwa keterampilan argumentasi siswa SMA Batik 1 Surakarta kelas X MIPA dan XI MIPA tergolong dalam kategori baik dengan persentasi setiap unsur argumentasi sebagai berikut: 68\% siswa menggunakan klaim ketika berargumentasi, $60 \%$ siswa menyertakan warrant (pembenaran atau alasan), 52\% siswa menggunakan data (bukti) dengan benar, 44\% siswa menggunkana backing (dukungan atau sumber) dan $0 \%$ rebuttal (sanggahan). Keterampilan argumentasi siswa kelas X MIPA dan XI MIPA SMA Batik 1 Surakarta memiliki perbedaan yang signifikan berdasarkan uji t yaitu dengan sig. (2-talied) 0,002, dengan persentase masingmasing unsur argumentasi sebagai berikut: 1) keterampilan memberikan klaim siswa kelas X MIPA sebanyak $63,11 \%$, sedangkan kelas XI MIPA 72,00\%; 2) warrant (pembenaran atau alasan) dari siswa $X$ MIPA 56,88\%, sedangkan kelas XI MIPA $63,10 \%$; 3) $44,40 \%$ siswa kelas X MIPA menggunakan data atau bukti di setiap jawaban yang diberikan, sedangkan siswa kelas XI MIPA 59,11\%; 4) 43,50\% siswa kelas X MIPA memberikan backing atau dukungan jawaban dengan mencantumkan sumber jawaban yang diberikan, sedangkan kelas XI MIPA sebanyak 44,40\%. 


\section{DAFTAR PUSTAKA}

Amin, M. (2010). Implementasi Hasil-Hasil Penelitian Bidang Biologi dalam Pembelajaran. Surakarta: Seminar Nasional Pendidikan Biologi FKIP UNS 2010.

Budiyono. (2016). Pengaruh Penerapan Model Pembelajaran Argument Based Science Inquiry (ABSI) terhadap Peningkatan Kemampuan Berargumentasi. Jurnal Pemikiran Penelitian Pendidikan dan Sains, 4(1), 84-93.

Cetin, P. S. (2014). Explicit Argumentation Instruction to Facilitate Conceptual Understanding and Argumentation Skills. Research in Science \& Technological Education, 32, (1), 1-20.

Farida, I., \& Gusniarti, W. F. (2014). Profil Keterampilan Argumentasi Siswa pada Konsep Koloid yang Dikembangkan melalui Pembelajaran Inkuiri Argumentatif. Edusains, VI(1), 33-40.

Ginanjar, W. S., Setiya Utari, \& Muslim. (2015). Penerapan Model Argument-Driven Inquiry dalam Pembelajaran IPA untuk Meningkatkan Kemampuan Argumentasi Ilmiah Siswa SMP. Jurnal Pengajaran MIPA, 20(1), 32-37.

Handayani, P., Murniati, \& Sardianto, M. S. (2015). Analisis Argumentasi Peserta Didik Kelas X SMA Muhammadiyah 1 Palembang dengan Menggunakan Model Argumentasi Toulmin. Jurnal Inovasi Dan Pembelajaran Fisika, 2(1), 60-68.

Ibda, F. (2015). Perkembangan Kognitif: Teori Jean Piaget. Intelektualita, 3(1), 27-38.
Miles, B. d. (1992). Analisa Data Kualitatif. Jakarta: UI Press.

Muslim, \& Suhandi, A. (2012). Pengembangan Perangkat Pembelajaran Fisika Sekolah untuk Meningkatkan Pemahaman Konsep dan Kemampuan Berargumentasi Calon Guru Fisika. Jurnal Pendidikan Fisika, 8, 174183.

Nurichah, E. F., Susantini, E., \& Wisant. (2012). Pengembangan Lembar Kegiatan Siswa Berbasis Keterampilan Berpikir Kritis pada Materi Keanekaragaman Hayati. BioEdu, 1(2), 45-49.

Probosari, R. M., Ramli, M., Harlita, Indrowati, M., \& Sajidan. (2016). Profil Keterampilan Argumentasi Ilmiah Mahasiswa Pendidikan Biologi FKIP UNS pada Mata Kuliah Anatomi Tumbuhan. Bioedukasi, 9(1), 29-33.

Sumarni, Widodo, \& Solihat. (2017). Stimulating Students Argumentation using Drawing - based Modeling on The Concept of Ecosystem. International Journal of Science and Applied Science, 2(1), 98-104.

Viyanti, Cari, Sunarno, W., \& Prasetyo, Z. K. (2016). Pemberdayaan Keterampilan Argumentasi Mendorong Pemahaman Konsep Siswa. Jurnal Penelitian Pembelajaran Fisika. Jurnal Penelitian Pendidikan Fisika, 7(1), 43-48.

Wahdan, W. Z., Sulistinab, O., \& Sukarianingsih, D. (2017). Analisis Kemampuan Berargumentasi Ilmiah Materi Ikatan Kimia Peserta Didik SMA, MAN, dan Perguruan Tinggi Tingkat I. Jurnal Pembelajaran Kimia, Vol 2 (2), 30-40. 